\title{
Consumo Colaborativo e Desenvolvimento de Negócio de Locação de Brinquedos Usando a Abordagem do Customer Development
}

\author{
Christiane Cunha Martini ${ }^{1}$ \\ Raquel Janissek-Muniz ${ }^{2}$ \\ Cláudia Melati ${ }^{3}$ \\ Daniela Francisco Brauner ${ }^{4}$
}

\begin{abstract}
Resumo
Apesar de estarmos inseridos em uma sociedade consumista, há espaço para o estabelecimento de novas formas de consumo. Este artigo trata sobre a modelagem de um novo negócio de locação de brinquedos para crianças em Porto Alegre. Ao invés de utilizar a abordagem tradicional de planejamento de empresas, elaborando um plano de negócios, optou-se por testar o modelo de Desenvolvimento de Clientes, sistematizado por Steve Blank. Nesse modelo a construção de um plano de negócios deve ser feita apenas após a fase de Descoberta do Cliente. $\mathrm{O}$ foco central deste trabalho foi modelar um empreendimento baseado em palpites iniciais, submeter essas hipóteses a testes junto a clientes em potencial e aprender com o feedback recebido, melhorando as definições preliminares. Os dados qualitativos foram obtidos através da realização de entrevistas em profundidade com 22 potenciais clientes. $\mathrm{O}$ resultado do processo de Descoberta do Cliente foi o desenvolvimento de um modelo de negócio com maior potencial de conquistar clientes e obter lucratividade, quando comparado aos primeiros palpites registrados.
\end{abstract}

Palavras-chave: Modelo de Desenvolvimento de Clientes; Consumo Colaborativo. Empreendedorismo; Modelo de Negócios.

\section{Collaborative Consumption and a Toy Rental Business Model Development Using the Customer Development Approach}

\footnotetext{
Abstract

${ }^{1}$ Possui graduação em Administração pela Universidade Federal do Rio Grande do Sul (2017). Atualmente é pesquisadora grupo IEAbrasil da Universidade Federal do Rio Grande do Sul e mestranda da Universidade Federal do Rio Grande do Sul. E-mail: christiane.martini@ufrgs.br

2 Graduação em Informática com ênfase em Análise de Sistemas pela UNIJUÍ-RS (1995), Mestrado em Administração pela Escola de Administração da UFRGS (2000), Master DEA MATIS na Université de Genebra/Suíça (2001), Master DEA en Systèmes dInformation pela Université Pierre Mendes France (2001), Doutorado em Sciences de Gestion pela Université Pierre Mendes France (2004) e Pós-Doutorado em Administração no GIANTI-PPGA/EA/UFRGS (2005-2006).E-mail: rjmuniz@ufrgs.br

${ }^{3}$ Servidora Pública Estadual junto ao Governo do Estado do Rio Grande do Sul. Graduação em Administração de Empresas pela Escola de Administração da Universidade Federal do Rio Grande do Sul (2010), Especialização em Administração Pública Contemporânea pela Universidade Federal do Rio Grande do Sul (2013), Mestre pelo Programa de Pós-Graduação em Administração da Escola de Administração da Universidade Federal do Rio Grande do Sul (PPGA/EA/UFRGS), atualmente Doutoranda do referido Programa. E-mail: cmelati@yahoo.com.br

${ }^{4}$ Professora adjunta na Universidade Federal do Rio Grande do Sul (UFRGS). Possui doutorado em Informática pela Pontifícia Universidade Católica do Rio de Janeiro. E-mail: daniela.brauner@ufrgs.br
} 
Although we are part of a consumer society, there is space for the establishment of new forms of consumption, such as the product services systems who deal with the rent and loan culture, as opposed to the acquisition. The autor prefered to test the Client Development model systematized by Steve Blank, instead of using the traditional approach to business planning, by designing a business strategy. In this model the construction of a business plan must be made only after the Customer Discovery's phase. The central focus of this work was to model a business based on initial presumptions, submit these hypothesis to tests with potential clients, and learn from the feedback received, improving the initial definitions. The result of the Customer Discovery process was the development of a business model with greater potential to conquer customers and gain profitability when compared to the first registered ideas.

Keywords: Customer Development Model; Collaborative Consumption; Entrepreneurship; Business Model. 


\section{Revista Gestão \& Sustentabilidade \\ Grupo de Estudos em Operações e Sustentabilidade}

\section{Consumo Colaborativo e desenvolvimento de negócio de locação de brinquedos usando a abordagem do Customer Development}

\section{Introdução}

A existência de produtos que satisfazem as mais singulares necessidades torna os atos de comprar, usar, armazenar e descartar tão naturais que passam despercebidos no dia a dia. Cada item consumido pela sociedade demanda o emprego de algum recurso para ser produzido e, fatalmente, deixará algum resíduo ao ser rejeitado. Botsman e Rogers (2011) afirmam que só nos últimos 50 anos já consumimos mais bens e serviços do que em todas as gerações anteriores. Como os recursos dos quais dispomos para a produção são finitos, se faz urgente e necessário achar um modelo de consumo mais sustentável. Diversas iniciativas têm questionado a mecânica atual de comercialização, trazendo à tona a preocupação com as relações sociais e o meio ambiente.

$\mathrm{O}$ ato de consumir em excesso não é inerente ao ser humano, é um hábito adquirido através da convivência em sociedade. Exemplo disto é o consumo de brinquedos, que evidencia o comportamento de consumo excessivo. Desde pequenas as crianças são estimuladas a desejar produtos que não precisam como presente de Natal ou aniversário. Mesmo que nada necessitem, as crianças são encorajadas a pedir alguma coisa, condicionando sua realização e bem-estar ao recebimento do presente pedido. Não raro acabam frustradas por não terem recebido o modelo sonhado, a quantidade solicitada ou a marca desejada, tornando estressante a experiência.

Segundo uma pesquisa realizada pelo Grupo NPD, em 2016 o consumo de brinquedos faturou cerca de 88,8 bilhões de dólares ao redor do mundo. Só nos Estados Unidos a receita proveniente desse mercado chegou a 20,4 bilhões de dólares no mesmo ano. No Brasil, um estudo divulgado pelo Serviço de Proteção ao Crédito e pela Confederação Nacional de Dirigentes Lojistas (2017) revelou que 11\% dos pais entrevistados pretendiam deixar de pagar alguma conta para presentear seus filhos no natal de 2017. Em outra pesquisa realizada pelo SPC Brasil (2015) foi constatado que uma em cada cinco crianças toma a decisão final na compra de brinquedos e jogos; seu grau de influência chega a 7 em uma escala de zero a dez. A pesquisa aponta ainda que $30 \%$ dos pais percebem a insaciedade dos filhos em relação às compras e, mesmo comprando boa parte dos itens que as crianças almejam, elas permanecem insatisfeitas, desejando novos produtos.

A evolução humana, o progresso tecnológico e o interesse publicitário transformaram o ato de consumir; antes o consumo era para subsistência, depois passou a abarcar necessidades secundárias (Maurer, Barcellos, Figueiró, Campos \& Silva, 2015). Com a produção de bens cada vez mais descartáveis, atrelado ao poder do marketing, a sociedade tornou o ato de consumir um ritual que satisfaz distintas necessidades. A cultura do consumo é estimulada pela propaganda, na qual o foco das vendas deixa de ser o produto e passa a destacar os sentimentos que a pessoa vai experimentar com a aquisição daquele bem. Desse modo, uma pessoa compra um carro pensando no sentimento de liberdade que ele vai lhe proporcionar, ou compra uma roupa nova para suprir sua falta de autoestima.

O consumismo infantil é uma realidade mundial que vem sendo cada vez mais discutida pela sociedade. Segundo o relatório da Associação Brasileira dos Fabricantes de Brinquedos (ABRINQ) de 2017, no Brasil, o faturamento com a venda de brinquedos aumentou quase $7 \%$ em 2016, chegando a movimentar mais de seis bilhões de reais. A pesquisa divulgada pelo SPC Brasil (2015) apurou que 64\% das mães entrevistadas adquirem produtos desnecessários quando solicitado pelos filhos e metade das compras de brinquedos, jogos, roupas e calçados são realizadas por impulso. Romper com este ciclo requer reflexão e 


\section{Revista Gestão \& Sustentabilidade Grupo de Estudos em Operações e Sustentabilidade}

força de vontade para modificar a forma como encaramos a posse de bens. Para Botsman e Rogers (2011, p. 83), deter a propriedade de um produto ou serviço não é essencial, o que realmente importa é o benefício que ele produz. Ter a possibilidade de usufruir das vantagens proporcionadas pelo uso de um equipamento, sem a necessidade de comprá-lo, se torna interessante do ponto de vista econômico, ambiental e social.

Nesse contexto verifica-se uma conjuntura favorável para o mercado de locação de produtos, principalmente aqueles relacionados à primeira infância. Para cada fase do desenvolvimento infantil existem diferentes tipos de brinquedo para estimular e entreter os pequenos apropriadamente. É comum que, neste processo, a criança rapidamente perca o interesse em um item, pois passou para um novo estágio de crescimento e, para manter as crianças curiosas e interessadas, os pais acabam comprando novos artigos. A consequência de alimentar esse ciclo é o acúmulo de produtos não usados. Esse processo não é sustentável, ocupa espaço e custa muito dinheiro.

Botsman e Rogers (2011) apresentaram um modelo de negócio baseado no aluguel de brinquedos para crianças. No exemplo, os pais, mediante uma assinatura, alugam brinquedos por um determinado período e depois trocam por outro diferente quando aquele item se tornar dispensável para a criança. Existem diversas empresas que oferecem esse serviço ao redor do mundo e no Brasil, desde 2010, esta atividade já é oferecida por alguns estabelecimentos.

Dessa forma, ao invés dos produtos ficarem esquecidos em uma residência, eles podem rodar pela casa de outras crianças que poderão aproveitá-lo, reduzindo a necessidade de compra dessas famílias. O efeito benéfico pode ser ainda mais profundo, pois "à medida que estes canais de distribuição se tornarem integrados com os próprios fabricantes de produtos, será do interesse deles tornar seus produtos mais duráveis a fim de lidar com múltiplos usuários e uso intensivo" (Botsman \& Rogers, 2011, p. 88). Adicionalmente, esse modelo de negócio possibilita que as crianças tenham contato com diferentes brinquedos adequados para cada fase de desenvolvimento. Não comprando itens, os pais economizam dinheiro, espaço e ainda auxiliam na redução de geração de resíduos. Além disto, a criança passa a ter contato com conceitos relacionados à sustentabilidade e consumo compartilhado, contribuindo para que desde pequenos compreendam que a diversão não está na posse do brinquedo, mas no seu uso. Neste sentido, o estabelecimento de um negócio neste ramo torna-se atraente.

\section{Problema de pesquisa e objetivo}

A temática deste artigo surgiu da percepção da problemática do alto custo de aquisição de produtos para a primeira infância quando comparados ao seu tempo de uso. Na pesquisa por alternativas de consumo, foi localizada uma empresa paulistana que loca desde bombas para aleitamento, cadeiras de transporte infantil até brinquedos, entretanto, com atendimento restrito a cidade de São Paulo. Ao continuar a busca por empresas do ramo no Rio Grande do Sul, localizou-se duas empresas que trabalham com a locação de brinquedo infantil para o dia a dia em Porto Alegre. Foi neste contexto, considerando a natureza volátil do interesse das crianças, que surgiu a ideia de modelar uma empresa para locação de brinquedos para crianças até seis anos de idade. Apesar de existirem estabelecimentos que já atendem a esta demanda, percebe-se que a proposta ainda é pouco explorada em Porto Alegre, havendo potencial para o seu desenvolvimento, visto que o Rio Grande do Sul é o sexto estado brasileiro que mais consome brinquedos: $5,5 \%$ das vendas nacionais são realizadas para o estado gaúcho (ABRINQ, 2017).

Neste contexto, a questão geral que a presente pesquisa busca responder é: Como podemos amenizar o problema com o acúmulo de brinquedos nos lares? O objetivo é elaborar um modelo de negócios para um novo empreendimento de aluguel de brinquedos para 


\section{Revista Gestão \& Sustentabilidade Grupo de Estudos em Operações e Sustentabilidade}

crianças na cidade de Porto Alegre. Para atingi-lo será elaborado um modelo de negócios baseado em hipóteses iniciais, as quais serão testadas junto aos clientes potenciais; em seguida será elaborado um mínimo produto viável (MVP) e, com a análise dos dados, será elaborada a versão final do modelo de negócio. Para modelar o negócio foi adotado o modelo de Desenvolvimento de Clientes sistematizado por Steve Blank (2012), utilizando o Modelo de Negócios Canvas de Osterwalder e Pigneur (2011). O modelo de negócios elaborado foi testado e validado como parte do processo de desenvolvimento do cliente. A versão final do modelo de negócios traz informações importantes para estabelecer um novo empreendimento de aluguel de brinquedos em Porto Alegre.

\section{Fundamentação Teórica}

Para embasar a implementação de uma nova empresa no mercado, buscamos elementos referenciais relacionados ao empreendedorismo, seguido da abordagem dos conceitos alusivos ao consumo colaborativo, consultando elementos de modelagem de negócios Canvas e a sistematização do modelo de Desenvolvimento de Clientes.

\subsection{Empreendedorismo}

Schumpeter (1964, p. 75) define o empreendedor como a pessoa que destrói a ordem econômica vigente através da introdução de novos produtos e serviços, do desenvolvimento de diferentes formas de organização ou pela exploração de novos processos, recursos e materiais. Para Gerber (1996, apud Farah, Cavalcanti \& Marcondes, 2008, p. 3) a personalidade empreendedora tem a capacidade de transformar "a condição mais significante numa excepcional oportunidade".

Hisrich e Peters (2004) destacam quatro fases do processo empreendedor: (1) identificar e avaliar a oportunidade, detectando oportunidades e necessidades em potencial para criar produtos ou serviços que a atenda melhor; (2) desenvolver o plano de negócios, elaborando um documento que sintetiza o propósito e a estratégia da empresa; (3) determinar os recursos necessários, consistindo na busca pelos recursos para aplicar no empreendimento; (4) administrar a empresa resultante, fase de gerenciamento da empresa. Nesta fase o plano de negócios é posto em prática e é onde surgem os problemas da vida real.

A decisão de abrir um negócio pode ser tomada para atingir realização pessoal, ou então pode ser a forma mais eficaz de gerar renda em uma economia em retração, que não oferece muitas possibilidades no mercado. Segundo a pesquisa da Global Entrepreneurship Monitor (GEM, 2017 , p. 29) as duas principais motivações para empreender são: (1) pela necessidade de gerar renda, tendo em vista a dificuldade para a recolocação do profissional; (2) identificação de uma oportunidade de negócio, mesmo tendo alternativas de emprego e geração de renda.

Essa mesma pesquisa aponta que a cada 100 empreendedores brasileiros, 57 empreenderam por oportunidade em 2016 (GEM, 2017, p. 30). Considerando os anos anteriores, vê-se que empreendedorismo por necessidade vem cedendo espaço para o empreendedorismo por oportunidade, ou seja, no Brasil os novos empreendedores estão estabelecendo negócios por detectarem uma chance de sucesso e não apenas por não terem alternativa de renda (GEM, 2017, p. 14).

A taxa total de empreendedorismo caiu de 39,3\% em 2015 para 36\% em 2016 no país (GEM, 2017, p. 23). Apesar da queda, a taxa registrada em 2016 foi a segunda maior atingida pelo país desde 2002, o que indica uma consolidação do empreendedorismo como opção ao emprego celetista, além disso, verifica-se a sua "crescente importância para a manutenção do nível de atividade econômica no Brasil, uma vez que a atividade de empreender correlaciona- 


\section{Revista Gestão \& Sustentabilidade Grupo de Estudos em Operações e Sustentabilidade}

se diretamente ao PIB e ao contexto socioeconômico nacional" (GEM 2017 p. 26). O principal desafio é transformar o empreendedorismo por necessidade em oportunidade e desenvolvimento. Neste sentido, aliar empreendedorismo a negócios colaborativos pode ser uma combinação que trará, além de novas oportunidades de negócios, um espaço sustentável para a sociedade e o ambiente.

\subsection{Consumo colaborativo}

O termo "consumo colaborativo" foi cunhado por Algar em 2007. Para ele, o consumo colaborativo descreve a prática de partilha, empréstimos comerciais, aluguel e trocas, transposta para a realidade do século XXI (Algar, 2007). O economista norte-americano Jeremy Rifkin (Oliveira, 2015) acredita que "o capitalismo está dando à luz uma espécie de filho, que é a economia do compartilhamento e dos bens comuns colaborativos".

Botsman e Rogers (2011) acreditam que vem ocorrendo uma profunda mudança na forma como consumimos. Cada vez mais as pessoas estão experimentando comportamentos relacionados à colaboração, ao compartilhamento de recursos e ao fomento de comunidades. O consumo colaborativo vem sendo fortemente impulsionado pela evolução da tecnologia, que aproxima pares que desejam prover e usufruir de recursos compartilhados. Segundo os autores essas interações possuem quatro princípios básicos:

- O princípio da massa crítica relacionado às escolhas e ao grupo de usuários, que devem ser suficientes para tornar o sistema de consumo colaborativo autossustentável;

- O princípio da capacidade ociosa diz respeito ao nível de inatividade de um bem;

- O princípio da crença no bem comum se refere aos bens de uso público, uma vez que novas formas de interação vêm aproximando pessoas cujos interesses são comuns e que consideram interessante tanto contribuir, quanto consumir o conteúdo compartilhado;

- O princípio da confiança entre desconhecidos diz respeito à autogestão que os usuários de bens comuns praticam, desde que tenham as ferramentas adequadas. Este autocontrole é realizado através da avaliação entre os pares, com avaliação de experiência, formando uma reputação online usada para avaliar futuros negócios.

Botsman e Rogers (2011) classificam as iniciativas de consumo colaborativo em três sistemas distintos: sistemas de serviços de produtos, mercados de redistribuição e estilos de vida colaborativos. Os sistemas de serviços de produtos estão relacionados à ideia de empréstimo e aluguel de bens, ao invés da aquisição. Os mercados de redistribuição dão conta da troca e doações de produtos, ao invés da compra. Já os estilos de vida colaborativos tratam sobre troca de ativos intangíveis como tempo, espaço, habilidades e dinheiro (Maurer et al., 2015). Simplificar a forma como o ser humano consome não deixará lacunas com necessidades não atendidas; pelo contrário, o consumo colaborativo continua satisfazendo as mesmas necessidades do consumo de massa (Botsman \& Rogers, 2011), permitindo uma redução na geração de resíduos, além de estimular uma cultura de consumo mais consciente.

\subsection{Modelo de negócios - Canvas}

Osterwalder e Pigneur (2011) consolidaram o Modelo de Negócios Canvas para descrever, analisar e projetar modelos de negócios, com uma estrutura que descreve a lógica de criação, entrega e captura de valor por parte de uma organização. A estrutura do Canvas (Figura 1), apresenta os aspectos mais relevantes necessários para traçar a estratégia de uma empresa, sendo representado por componentes que, quando elaborados conjuntamente, explicitam a lógica de geração de valor elaborada pelo empreendedor. 
Figura 1. O quadro do Modelo de Negócios Canvas.

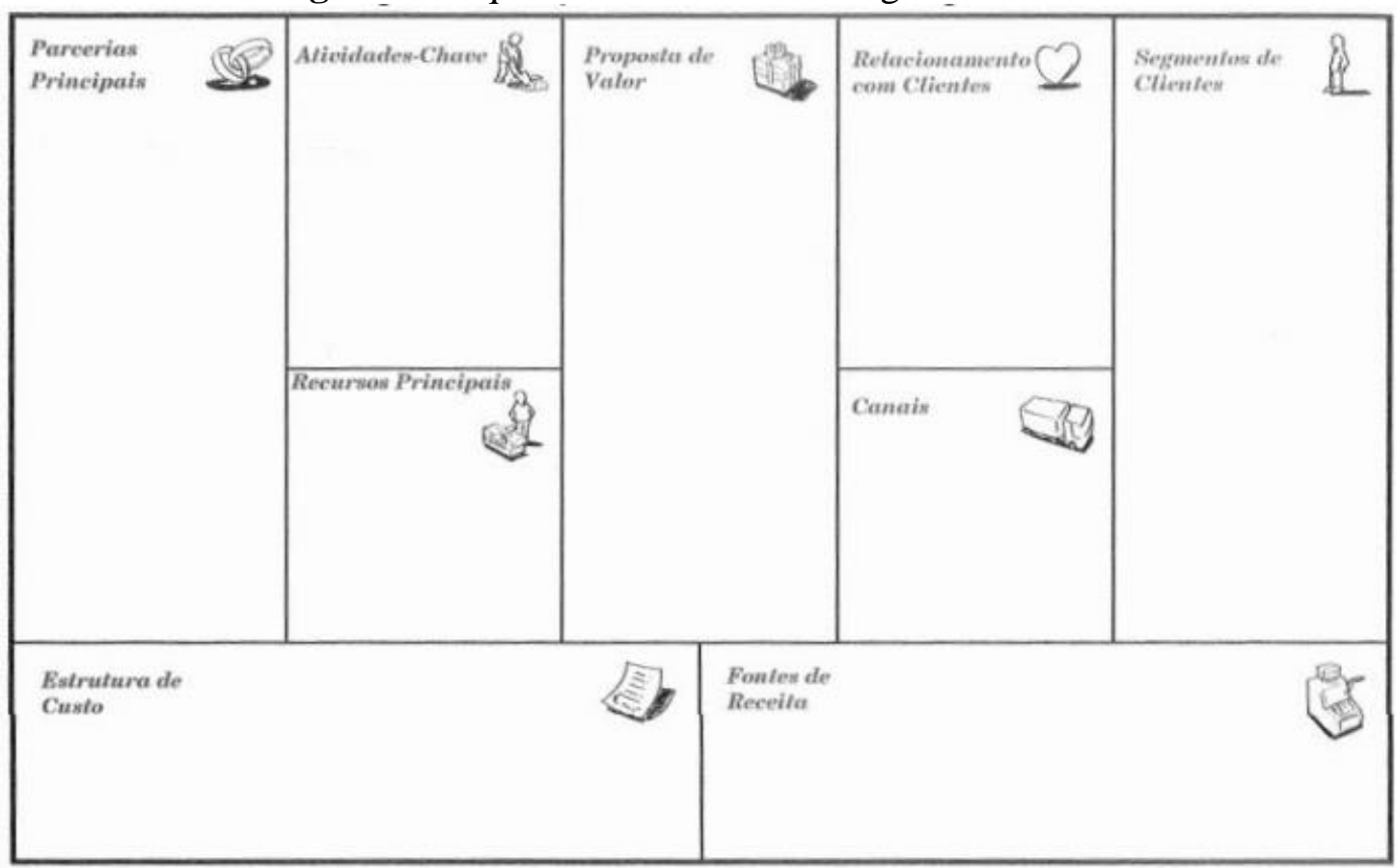

Fonte: Recuperado de Osterwalder e Pigneur (2011, p. 44).

No Segmento de clientes define-se os clientes que vão comprar a solução apresentada pelo empreendedor; os clientes são agrupados em segmentos distintos, cada qual com necessidades, comportamentos e atributos. No item Relacionamento com o cliente a empresa deve esclarecer o tipo de relação que quer estabelecer com cada Segmento de Cliente; as três principais estratégias de relacionamento apontadas são: conquista de clientes, retenção de cliente e ampliação das vendas. Nos Canais deve-se listar os meios pelos quais a empresa vai chegar a cada segmento de clientes para entregar a proposta de valor, encontrando um mix de canais apropriado para fazer contato com os clientes. Os canais podem ser particulares e em parceria, sempre buscando criar a melhor experiência possível para o cliente com base no conjunto de canais selecionados. A Proposta de Valor ofertada é o motivo pelo qual os clientes escolhem uma empresa ou outra, havendo necessidade de identificar uma proposta de valor que atenda aos interesses desses clientes. As Atividades-chave são as principais ações necessárias para que a empresa entregue a proposta de valor para cada segmento de cliente, envolvendo produção, resolução de problemas e plataforma.

Recursos são os meios fundamentais necessários para que a empresa tenha êxito, e envolvem recursos físicos, financeiros, intelectuais e humanos. Em Parcerias devem ser listados os fornecedores e parceiros necessários para o funcionamento do negócio, buscando defini-los visando união para reduzir riscos e custos, fortalecendo o modelo de negócio.

As Fontes de receita são determinadas pelo dinheiro gerado pela empresa a partir de cada segmento de clientes; a empresa deve descobrir quanto cada grupo está disposto a pagar pela proposta de valor ofertada. Uma forma de gerar receita exposta pelos autores é a de Empréstimo ou Aluguel; neste tipo de transação o consumidor passa a ter acesso a um bem ou serviço pelo tempo que comprou: os locadores ganham com a recorrência da receita e os locatários se beneficiam por usufruírem do bem sem precisar pagar por seu valor integral. A 
Estrutura de custos deve especificar quais são os custos mais significativos para a empresa operar. Distingue-se duas classes de estrutura de custos: direcionadas pelo custo e pelo valor. O direcionamento pelo custo foca em minimizar ao máximo a estrutura de custos da empresa, enquanto o direcionamento pelo valor prioriza a entrega com alto nível de personalização para o cliente. Estes nove componentes formam o Modelo de Negócios, ferramenta base para a aplicação do modelo de Desenvolvimento de Clientes, descrito a seguir.

\subsection{Modelo de Desenvolvimento de Clientes (Customer Development)}

O modelo de Desenvolvimento de Clientes (Figura 2), tem como objetivo entender as necessidades e anseios dos clientes para desenvolver uma solução que eles queiram consumir, antes da empresa se comprometer com uma trajetória determinada (Blank, 2012).

Figura 2. O modelo de Desenvolvimento de Clientes.

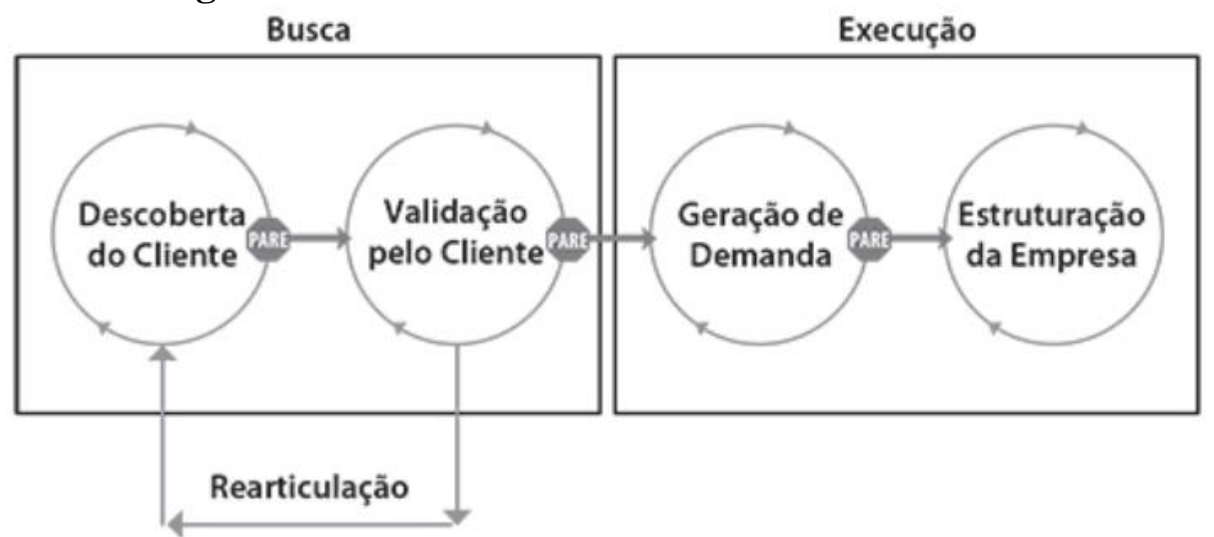

Fonte: Recuperado de Blank e Dorf (2014).

Este modelo é uma alternativa ao modelo clássico de planejamento de negócios, e pode ser utilizado tanto por empresas já consolidadas quanto por startups. Através do modelo é possível descobrir para quem a empresa vai vender e por quê as pessoas vão comprar o produto. O modelo é constituído por quatro passos, e a realização de cada passo está formatada por uma linha circular com setas recursivas, enfatizando o fato de que cada etapa do desenvolvimento de clientes é iterativa e passível de ser repetida (Blank, 2012). Na Descoberta do Cliente os fundadores descrevem sua visão de produto para levantar hipóteses de como seria o modelo de negócios baseado na ideia inicial. Em seguida, é estabelecido um conjunto de testes para averiguar as reações dos clientes objetivando validar ou não as hipóteses levantadas. O segundo passo é a Validação pelo Cliente onde se verifica se o modelo de negócio é escalável; em caso negativo, é preciso rearticular o modelo e voltar para o primeiro passo. Na Geração de Demanda os fundadores têm um modelo de negócio escalável e podem iniciar a execução. Somente na última etapa é feita a Estruturação da Empresa, onde a startup deixa este status para se tornar uma empresa com foco na execução de um modelo de negócios aprovado (Blank, 2012). Neste artigo será registrado o processo de descoberta de clientes, determinante para o modelo de Desenvolvimento de Clientes.

\subsubsection{Descoberta do cliente}

A descoberta do cliente é composta por quatro fases (Figura 3): (1) Definição das hipóteses; (2) Teste do problema; (3) Teste da solução; e (4) Verificação.

Figura 3. Fases do processo de Descoberta do Cliente. 


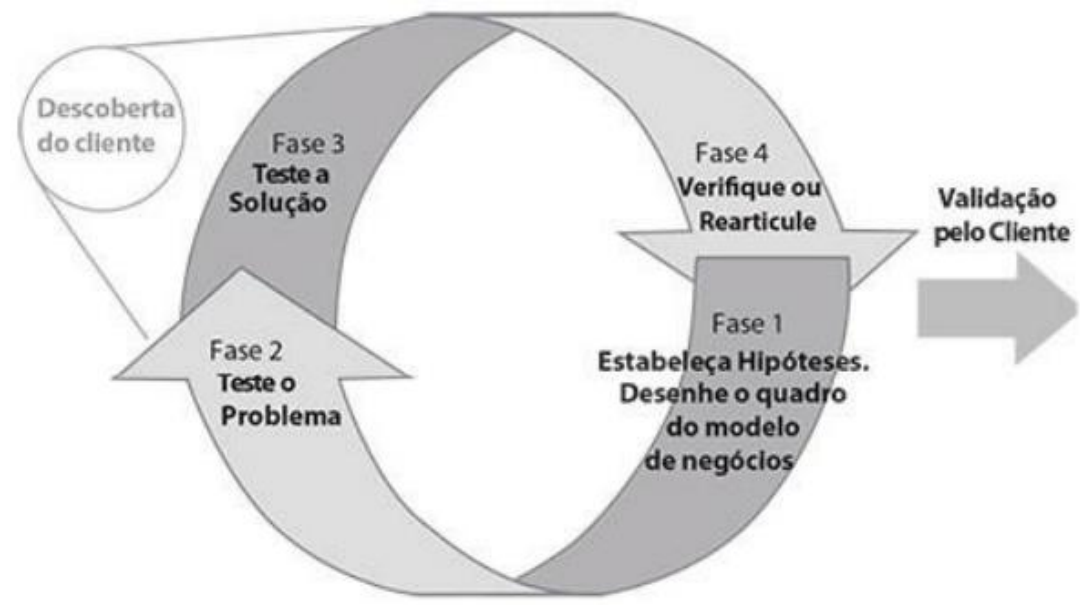

Fonte: Recuperado de Blank (2012, p. 53).

Na Fase 1 deve ser realizado o levantamento das hipóteses preliminares da startup que devem ser registradas em um briefing. É preciso colocar no papel todas as conjecturas acerca do produto, clientes, problema, preço, distribuição, demanda, tipo de mercado e concorrência. Após a elaboração do briefing é possível construir a primeira versão do Modelo de Negócios Canvas. Com esse primeiro quadro da empresa determinado, é possível passar para a fase de teste do problema.

Na Fase 2 as hipóteses levantadas serão postas à prova no mundo real. O passo a passo inicia com contatos amigáveis, seguido pela apresentação do problema, compreensão do cliente e encerra com o conhecimento do mercado. Na Fase 3 o conceito do produto é testado com clientes no mercado potencial. Esta etapa inicia com a primeira verificação da realidade, seguida da apresentação do produto; depois são realizadas mais visitas aos clientes para efetuar outras verificações da realidade, encerrando com a definição do primeiro conselho consultivo. Com as três primeiras fases finalizadas, o empreendedor já testou se as hipóteses levantadas inicialmente estavam certas. Na última fase deve-se verificar se o modelo de negócios definido é financeiramente viável. Para auxiliar na decisão, o autor determina quatro etapas: verificação do problema, verificação do produto, verificação do modelo de negócio, definição de perseverar ou parar. $\mathrm{O}$ empreendedor deve seguir adiante somente com essas questões respondidas, sendo etapa fundamental para o sucesso do processo de desenvolvimento do cliente. Apresentar ao cliente um mínimo produto viável (MVP) permite antecipar potencialidades de aplicação.

\subsubsection{Minimum Viable Product - MVP}

O mínimo produto viável é o conjunto mínimo de características do produto, ou seja, contém as características básicas necessárias para que o cliente decida pagar por um bem ou serviço em seu primeiro lançamento. Blank (2012, p. 69) afirma que "a premissa é que um grupo de clientes visionários vai orientar a continuidade dos atributos disponibilizados a cada lançamento". A pergunta a ser respondida é "Qual é o menor ou menos complicado problema que o cliente nos pagaria para resolver?" (Blank, 2012, p. 69). Ao apresentar o MVP para possíveis clientes a startup consegue coletar feedbacks úteis e gerar aprendizado sobre o mercado rapidamente. Blank e Dorf (2014) sugerem o uso do que nomeiam como MVP de Baixa Fidelidade para expor aos clientes em potencial o produto que está sendo desenvolvido. O diferencial do MVP de baixa fidelidade consiste na apresentação do problema que os fundadores identificaram sem a necessidade de produzir um protótipo (que representa o MVP de Alta Fidelidade). 


\section{Revista Gestão \& Sustentabilidade Grupo de Estudos em Operações e Sustentabilidade}

\section{Método de pesquisa}

Este trabalho, de abordagem qualitativa, foi realizado através de uma pesquisa aplicada, utilizando dados primários e secundários. Segundo Gerhardt e Silveira (2009) a pesquisa aplicada tem como objetivo desenvolver conhecimento para a aplicação prática, o que vai ao encontro do objetivo principal deste trabalho que é modelar um negócio para ser estabelecido em Porto Alegre. Segundo Malhotra (2012) dados primários são coletados e elaborados pelo próprio pesquisador para tratar do problema objeto do seu estudo. Os dados secundários são aqueles que não foram gerados pelo pesquisador e foram colhidos, tratados e publicados para um objetivo diverso daquele do problema definido na pesquisa (Malhotra, 2012, p. 36).

Para a coleta de dados primários utilizou-se a abordagem exploratória através da realização de entrevistas em profundidade. A pesquisa exploratória tem como principal meta auxiliar na compreensão do problema enfrentado pelo pesquisador (Malhotra, 2012), objetivando proporcionar maior familiaridade com o problema, com vistas a torná-lo mais explícito, constituir hipóteses e aprimorar ideias. O planejamento é bastante flexível, de modo que possibilite a consideração dos mais variados aspectos relativos ao fato estudado (Gil, 2002). Esta abordagem é compatível com o modelo de Desenvolvimento de Clientes, em que é necessário levantar hipóteses e testá-las com o público-alvo. Para tal, foram realizadas 22 entrevistas em profundidade com roteiros semiestruturados, possibilitando a descoberta de motivações, crenças, atitudes e sentimentos sobre o assunto. As entrevistas foram realizadas com pais de crianças de 0 a 6 anos, apresentando as características do serviço de locação de brinquedos, visando coletar impressões e identificar o interesse dos entrevistados em relação ao negócio. Das entrevistas realizadas, $50 \%$ foram com pessoas que não haviam tido contato com serviços de locação de brinquedos e 50\% com usuários deste tipo de serviço, identificados através de páginas de rede social de empresas que alugam brinquedos em Porto Alegre. Após a coleta de dados foi realizada uma análise para verificar o grau de aprovação das hipóteses iniciais. Como recurso visual foi elaborada uma landing page (divulgada igualmente pela internet através do Facebook e Whats App) para explicar o funcionamento do serviço, com possibilidade de registro de e-mail para os interessados.

Os dados coletados foram submetidos à análise de conteúdo. Para Weber (1990, apud Roesch, 2012, p. 170) a análise de conteúdo "usa uma série de procedimentos para levantar inferências válidas a partir de um texto". Como as entrevistas foram realizadas com pessoas que já alugam brinquedos e com quem nunca teve contato com esse serviço, a análise de conteúdo buscou verificar diferentes elementos nas respostas de cada tipo de entrevistado. Nas entrevistas realizadas buscou-se verificar a compreensão do entrevistado em relação aos pontos positivos e o que percebe como pontos negativos, bem como buscar sugestões de melhorias acerca dos serviços. Nas entrevistas com quem ainda não conhecia o sistema de aluguel de brinquedos, o objetivo foi apurar se a proposta de valor está clara; se há interesse em contratar o serviço; em caso negativo, o que faria a pessoa mudar de ideia; além de verificar as dúvidas sobre a locação e sugestões para tornar a proposta mais atrativa.

\section{Análise dos resultados}

A análise dos resultados foi assim conduzida: foram definidas as hipóteses iniciais da empresa para cada elemento do modelo de negócio Canvas versão 1.0; depois as hipóteses foram apresentadas a uma mentora que sugeriu melhorias nas hipóteses iniciais para viabilizar a operação. Em seguida foi construído o modelo de negócio Canvas versão 2.0 que foi apresentado para clientes em potencial; com base nas entrevistas foi elaborado um MVP de 
baixa fidelidade para testar o grau de atratividade da proposta. Por fim foi consolidado o modelo de negócio Canvas versão 3.0 a proposta de valor da empresa e sua operação.

\subsection{Hipóteses iniciais - construção do Canvas versão 1.0}

A definição de hipóteses iniciais baseou-se na observação das práticas aplicadas por empresas que oferecem o serviço de locação de brinquedos, bem como por reflexões acerca da melhor forma de usar o serviço, através do ponto de vista dos clientes. Conforme modelo de Desenvolvimento de Clientes, foi registrado em um briefing as principais hipóteses de produto, cliente, preço, distribuição, demanda, mercado e concorrência, antes do preenchimento da primeira versão do quadro de Modelo de Negócios Canvas, a partir do que foi possível elaborar o Canvas versão 1.0 (Figura 4).

Figura 4. Modelo de negócios Canvas versão 1.0 - Hipóteses Iniciais.

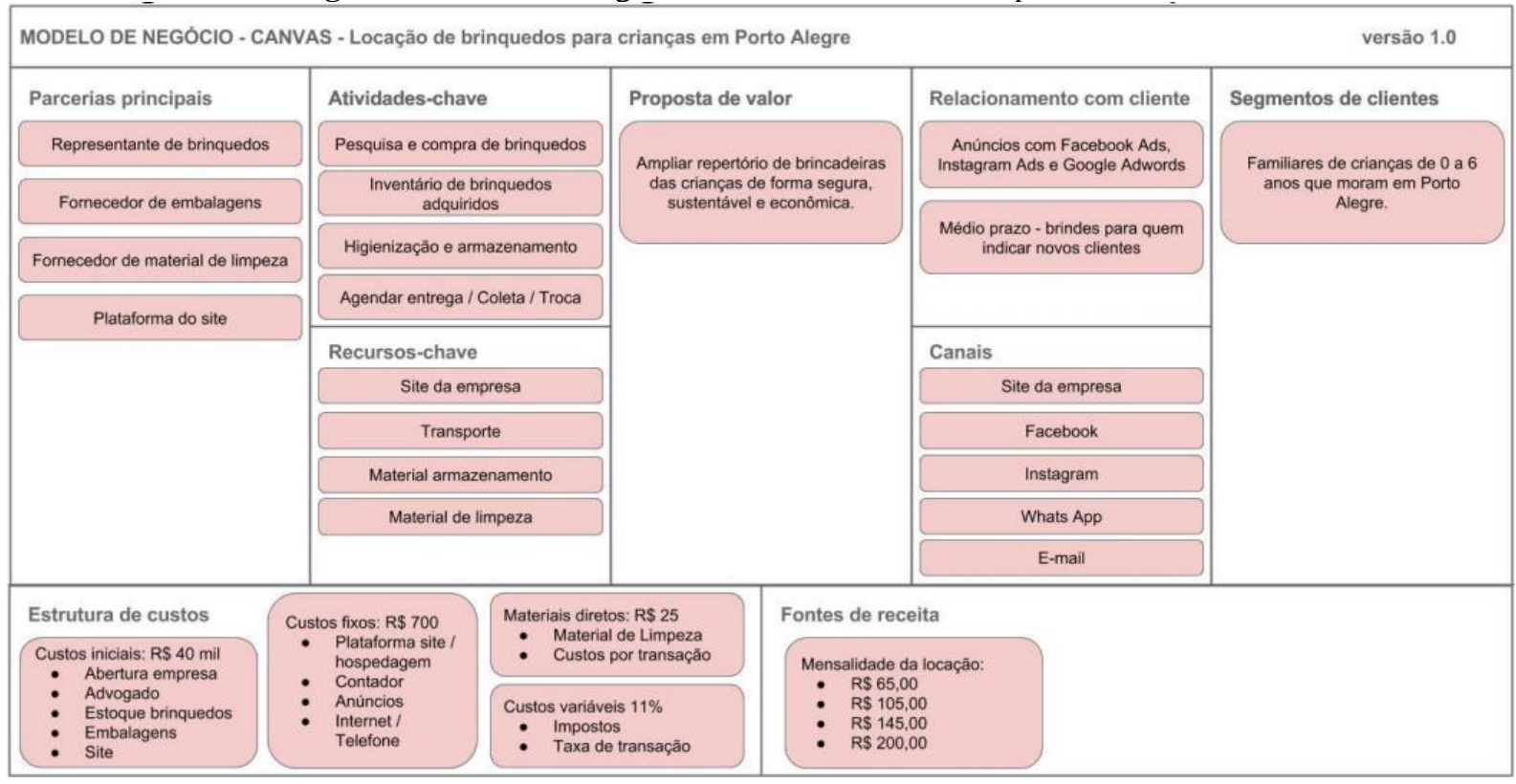

Fonte: Elaborado pelas autoras (2017).

O segmento de clientes definido na primeira versão do modelo de negócios foi o de familiares de crianças recém-nascidas até seis anos de idade que moram em Porto Alegre. Além dos pais, considerou-se que avós, tios e padrinhos poderiam se interessar pelo serviço. As suposições iniciais sobre a proposta de valor consideraram a natureza volátil do interesse das crianças por produtos. É muito comum comprar itens que são usados por pouco tempo e acabam esquecidos nos lares, ocupando espaço sem ter utilidade. A partir de reflexões preliminares, admitiu-se a possibilidade de este ser o quadro padrão nas famílias de Porto Alegre, considerando que o acúmulo de brinquedos nos lares seria o problema a ser resolvido. Para tal sugere-se a locação de brinquedos. Na entrega dos mesmos poderão ser explicadas as formas de uso do item, sendo igualmente feita uma vistoria presencial para analisar as condições do produto, antes de coletar a sua assinatura no termo de recebimento. Para garantir a segurança das crianças, todos os brinquedos disponíveis devem ser certificados pelo INMETRO. Em síntese, a proposta de valor é oferecer a possibilidade de ampliar o repertório de brincadeiras das crianças de forma segura, sustentável e econômica.

O conjunto de canais sugerido é essencialmente digital e cada qual desempenhará um papel específico. Sugere-se o seguinte mix: site da empresa, Whats App, Facebook, Instagram e E-mail. O site da empresa é vital para o negócio, pois será somente através dele que os clientes poderão contratar o serviço de locação de brinquedos e efetuar o pagamento. Esse 


\section{Revista Gestão \& Sustentabilidade Grupo de Estudos em Operações e Sustentabilidade}

canal centralizará a oferta de brinquedos, o recebimento dos pedidos, as informações para entrega, o controle do prazo de locação e os pedidos de renovação e troca. Além disso, páginas em redes sociais poderão ser utilizadas para divulgação do site em grupos de mães e pais de Porto Alegre, bem como o uso do Whats App para atendimento ao cliente, e o e-mail para formalização de pedidos e pagamentos realizados pelo site.

A estratégia de relacionamento selecionada inicialmente é a conquista de clientes. Para tal a empresa deve realizar um investimento em mídia online para divulgar o serviço. Recomenda-se o patrocínio de posts das redes sociais da empresa com o Facebook Ads e Instagram Ads. O uso do Google Adwords é indicado para divulgar o site da empresa para quem procurar no Google termos relacionados a locação de brinquedos em Porto Alegre. A principal fonte de receita é o valor do aluguel do brinquedo escolhido no site. Como serão oferecidos brinquedos com diferentes custos de aquisição, serão aplicadas mensalidades com preços vinculados ao seu valor de compra. Entre os principais recursos para a empresa operar estão os brinquedos para locação; disponibilização dos produtos no site; materiais para higienização, armazenamento e transporte dos produtos.

A primeira atividade-chave definida é a pesquisa e compra de brinquedos que tenham bom potencial para locação (aqueles que possuem um custo maior e que são usados por pouco tempo em decorrência do rápido crescimento da criança, como por exemplo o apoiador para a criança que está começando a caminhar). A segunda atividade-chave definida é o processo de inventário dos brinquedos comprados (criação de um check-list padrão para a inspeção do produto, catálogo de manuais, notas-fiscais, garantia e publicação do item para locação). A terceira atividade-chave é a higienização dos brinquedos que deve ser feita conforme a norma da ABNT NBR 16493. Outra atividade-chave é a entrega dos brinquedos (a empresa faz a entrega para o cliente no local e horário combinado e na oportunidade deverá explicar o seu funcionamento, realizar a vistoria do produto e coletar assinatura no termo de recebimento). A última atividade-chave detectada é a coleta e troca de brinquedos, sendo necessário agendar data, hora e local para coletar os brinquedos que serão inspecionados em conjunto com o cliente e também poderão ser entregues os brinquedos escolhidos para o mês seguinte.

As principais parcerias são os representantes de brinquedos, a plataforma de $e$ commerce, o fornecedor de embalagem e material de limpeza. Para localizar os representantes de brinquedos sugere-se o contato com o site oficial das principais marcas de brinquedos infantis, solicitando contato de distribuidores que atendam a cidade de Porto Alegre.

Inicialmente foram estimados os custos pré-operacionais, os custos fixos mensais, os custos variáveis e os custos com materiais diretos. Os investimentos pré-operacionais estimados ficam na ordem de $\mathrm{R} \$ 40.000,00$. Este valor contempla a compra de um estoque inicial de brinquedos, embalagens, desenvolvimento do site e custos com o estabelecimento da empresa incluindo orientação jurídica e fiscal. Os custos fixos mensais chegam a $\mathrm{R} \$$ 700,00, onde estão inclusos os custos com contador, hospedagem do site, telefone, internet, investimento em divulgação e outras despesas não previstas. Os custos com materiais diretos consideraram o custo médio da limpeza de cada item conforme a norma ABNT NBR 16493; o custo médio de entrega para a cidade de Porto Alegre; e a taxa por transação cobrada pelo sistema de pagamento online. Os custos variáveis englobam os impostos que a empresa deve pagar e demais custos por transação. Conforme o anexo III do Simples Nacional, as empresas de serviços com faturamento até 180 mil reais nos últimos 12 meses devem pagar a alíquota de $6 \%$ ao mês sobre a receita bruta. Foi inclusa também a tarifa de $5 \%$ por transação cobrada pelo sistema de pagamento online.

A formação do preço das mensalidades considerou a estimativa de custos com materiais diretos e custos variáveis. Descontando $11 \%$ de custos variáveis e custos com a prestação do serviço, há sobra de $\mathrm{R} \$ 32,62$ a $\mathrm{R} \$ 152,77$ por aluguel. Esse saldo contribui para o pagamento dos custos fixos da empresa e para a margem de lucro. Estimou-se que os 
investimentos pré-operacionais definidos arcarão com a compra de cerca de 54 brinquedos para o estoque inicial de locação. Supôs-se que $15 \%$ do investimento em brinquedos será em produtos que custam até $\mathrm{R} \$ 300,00 ; 30 \%$ com produtos que custam entre $\mathrm{R} \$ 301,00$ e $\mathrm{R} \$$ 600,$00 ; 30 \%$ com produtos que custam entre $\mathrm{R} \$ 601,00$ e $\mathrm{R} \$ 1000,00$; e $25 \%$ com produtos que custam mais de $\mathrm{R} \$ 1.000,00$. Com isso o faturamento mensal máximo previsto será $\mathrm{R} \$$ $5.805,00$. Considerando o faturamento máximo de $\mathrm{R} \$ 5.805,00$ e os custos envolvidos, a empresa teria como resultado líquido máximo cerca de $\mathrm{R} \$ 3.115,00$ por mês. No resultado líquido previsto não está estimado o pagamento de pró-labore ou salário. Esse resultado inferior ao que era imaginado no início da modelagem do negócio tornou-se um ponto de preocupação para a implementação do projeto, principalmente porque sabe-se que a receita máxima não será atingida nos primeiros meses de operação.

\subsubsection{Hipóteses iniciais e construção do Canvas versão 2.0}

Os primeiros contatos amigáveis para a apresentação das hipóteses iniciais foram realizados com pessoas próximas às autoras, com o objetivo de buscar indicações para potenciais clientes. Neste processo houve uma pessoa interessada em entender melhor a proposta, atuando como mentora. O quadro do modelo de negócios com as hipóteses iniciais foi apresentado a essa mentora que, ao longo de duas extensas reuniões, contribuiu para a lapidação de alguns componentes do modelo de negócios e para o aumento do resultado líquido esperado. As principais alterações do modelo de negócio estão listadas a seguir e a segunda versão do modelo de negócios pode ser vista na Figura 5.

Figura 5. Quadro modelo de negócios Canvas - versão 2.0.

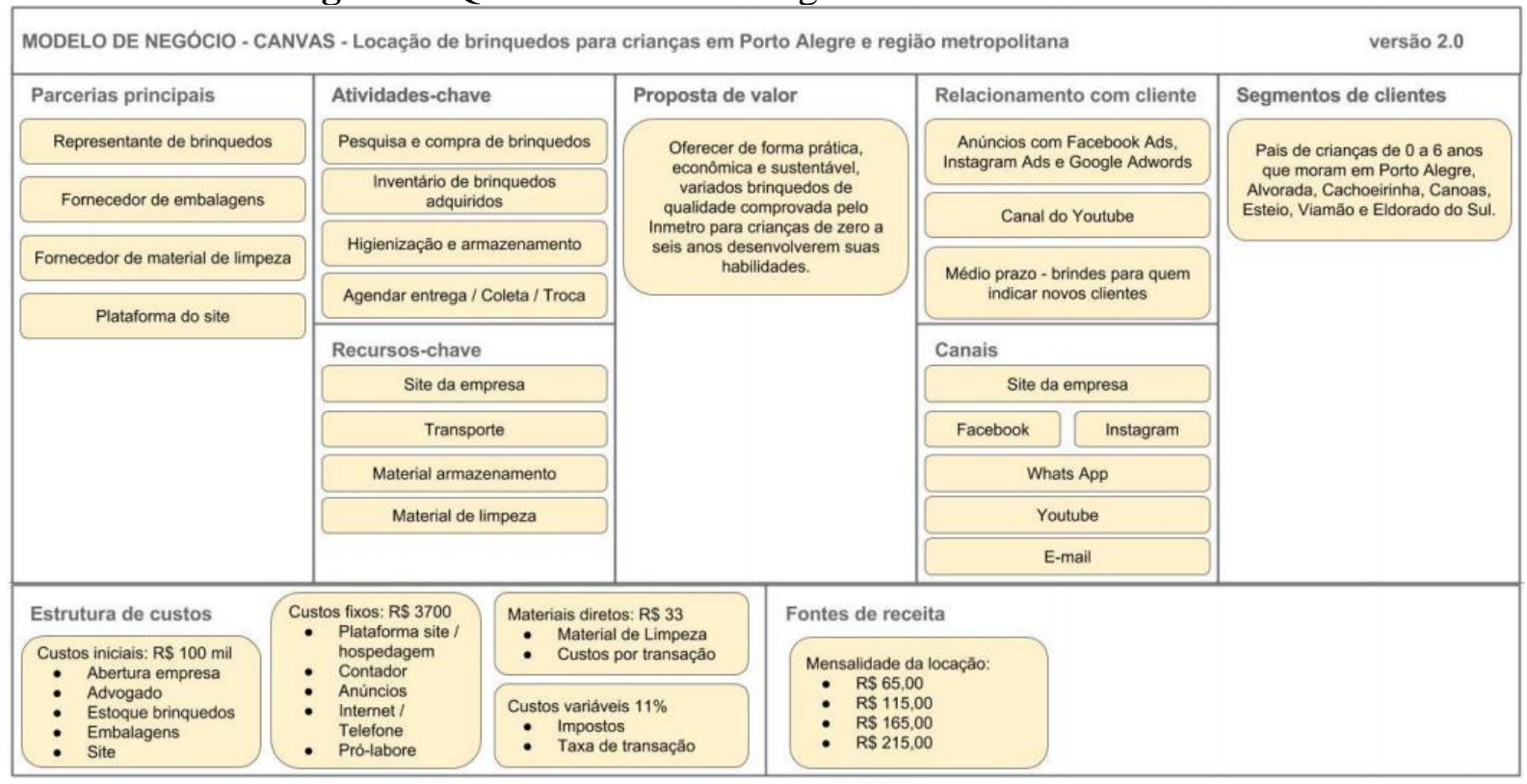

Fonte: Elaborado pelas autoras (2017).

Como os pais exercem papel fundamental na criação dos filhos, optou-se por delimitar o público-alvo em relação ao definido na primeira versão do modelo de negócios. O segmento de clientes redefinido é o de pais com filhos recém-nascidos até seis anos de idade que moram em Porto Alegre e cidades da região metropolitana. Foi ampliado o atendimento para algumas cidades da região metropolitana pois supôs-se que existe mercado e é financeiramente viável entregar os brinquedos em cidades vizinhas, sem necessidade de cobrar pelo frete.

Por entender que a saúde e a segurança são os principais pontos de preocupação dos pais com os filhos, optou-se por chamar a atenção para este cuidado na hora de consolidar a proposta de valor. A nova proposta de valor ficou assim sintetizada: Oferecer de forma 


\section{Revista Gestão \& Sustentabilidade Grupo de Estudos em Operações e Sustentabilidade}

prática, econômica e sustentável, variados brinquedos de qualidade comprovada pelo INMETRO para crianças de zero a seis anos desenvolverem as suas habilidades.

Além disto, admitimos a hipótese de que mães e pais constantemente estão envolvidos com atividades rotineiras que tornam o seu dia a dia bastante agitado e por isso o serviço de locação de brinquedos precisa ser simples e fácil. Dessa forma, as explicações sobre o funcionamento do brinquedo e a conferência das condições do item serão opcionais na entrega dos produtos. Quem optar por não receber as orientações pessoalmente poderá assistir no canal do YouTube da empresa um vídeo curto com as instruções de uso, incluindo tal canal de divulgação nas hipóteses iniciais. Com a entrada do YouTube no mix de canais da empresa, foi necessário incluir a gravação dos vídeos com as demonstrações de uso dos brinquedos durante o processo de inventariar os brinquedos adquiridos.

$\mathrm{Na}$ segunda versão do Canvas a principal fonte de receita continua sendo o valor do aluguel do brinquedo escolhido no site; no entanto modificou-se um pouco a precificação. A mensalidade mínima continuou a ser $\mathrm{R} \$ 65,00$, mas as faixas intermediárias tiveram seu preço aumentado. Em relação a plataforma de e-commerce verificou-se que será necessário contratar um programador para desenvolver uma solução personalizada, pois as soluções prontas são focadas na venda de produtos, não contemplando o processo de locação que prevê o retorno do produto e escolha de novos itens para a troca.

A estrutura de custos inicialmente projetada sofreu alterações principalmente nos investimentos pré-operacionais, custos fixos mensais e nos custos com materiais diretos. Os investimentos pré-operacionais aumentaram de $\mathrm{R} \$ 40.000,00$ para $\mathrm{R} \$ 100.000,00$. Com isto foi possível ampliar o estoque inicial de brinquedos e consequentemente o faturamento máximo possível. Foi incluído também um custo fixo mensal de $\mathrm{R} \$ 3.000,00$ para pró-labore. Os custos com materiais diretos aumentaram por conta da inclusão do atendimento de cidades da região metropolitana de Porto Alegre para entrega sem cobrança de frete. Essas mudanças culminaram na redistribuição dos investimentos na compra de estoque de brinquedos

Com as alterações na estrutura de custos idealizada na segunda versão do modelo de negócios, a empresa tem uma estimativa máxima de faturamento mensal de $\mathrm{R} \$ 18.457,00$. Descontando os custos e despesas o resultado mensal máximo estimado é de $\mathrm{R} \$ 8.016,00$. A sugestão da mentora é que esse resultado líquido seja distribuído da seguinte forma: $70 \%$ como remuneração dos investidores, $20 \%$ para reinvestir na empresa e $10 \%$ como reserva financeira. Desta forma o retorno do investimento ocorreria em aproximadamente 18 meses de faturamento máximo atingido.

\subsection{Apresentação das hipóteses do Canvas 2.0}

As hipóteses levantadas na segunda versão do Canvas foram testadas através de entrevistas em profundidade com 22 pais de crianças que moram ou trabalham em Porto Alegre e região metropolitana. Todos entrevistados têm filhos, em sua maioria meninos com idades entre um e dois anos. Cerca de $68 \%$ dos pais que responderam a entrevista estão na faixa etária que vai dos 30 a 40 anos; $73 \%$ são mulheres e $27 \%$ são homens; a maioria dos entrevistados, cerca de $45 \%$, tem renda mensal familiar entre 4 e 10 salários mínimos; e $27 \%$ dos entrevistados atuam como autônomos. Em relação aos hábitos de compra destes pais, a maioria costuma gastar de 30 a 50 reais em brinquedos mensalmente. Grande parte mencionou que costuma comprar presentes melhores em ocasiões especiais. O principal fator para decisão de compra é o interesse da criança; a segurança também é muito considerada e o propósito de desenvolvimento costuma ser bem relevante na hora de adquirir novos itens.

Mais de $80 \%$ dos entrevistados relataram já ter comprado ou ganho brinquedos que foram muito pouco usados e ficaram ocupando espaço em casa. Para $78 \%$ dos entrevistados, o acúmulo de brinquedos inúteis é um problema. Os destinos para os brinquedos sem uso são diversos: armazenamento, doação, troca, empréstimo e venda. Boa parte dos entrevistados 


\section{Revista Gestão \& Sustentabilidade Grupo de Estudos em Operações e Sustentabilidade}

mencionou que guarda os brinquedos mais caros para oferecer novamente à criança. Os itens mais caros também são guardados por pais que pensam em ter mais filhos e querem dispor do brinquedo no futuro. Os itens mais baratos normalmente são encaminhados para doação. Vários pais mencionaram que costumam emprestar ou trocar itens com familiares e conhecidos. A revenda de brinquedos foi mencionada em poucas entrevistas.

Algo que surpreendeu durante as entrevistas foi alguns pais apontarem que esse serviço seria interessante para testar produtos antes de comprar. Eles relataram que evitam comprar alguns brinquedos caros porque imaginam que os filhos logo vão perder o interesse, então esse serviço seria útil para verificar se realmente vale a pena comprar o item ou se é apenas um interesse passageiro.

Como pontos negativos para locação de brinquedos os pais apontaram o preço da locação como possível impeditivo para contração do serviço e a possibilidade de não ter disponível o brinquedo desejado pela criança de forma recorrente. Foram destacadas também a preocupação com a higienização e logística de entrega. Durante as entrevistas surgiram duas preocupações que não haviam sido tratadas na exposição da proposta inicial. Alguns pais procuraram saber como a empresa lidaria com perdas e avarias nos brinquedos locados e se teria a opção de comprar o brinquedo, caso a criança se apegue muito ao produto. Em relação ao apego propõe-se que os pais tenham a possibilidade de comprar aqueles brinquedos que a criança realmente deseja manter em sua casa. Como a proposta de valor da empresa foca na diversidade e sustentabilidade, este tipo de prática deve ser exceção. $\mathrm{O}$ valor da mensalidade de renovação poderá ser abatido do valor que o cliente for pagar pela posse do produto.

Sobre os problemas com danos nos brinquedos e perda de peças, foi apresentado o que as empresas atualmente praticam. Em caso de perda de peças, costuma-se dar um prazo para os locatários encontrarem a peça na sua casa, sem a cobrança de multas. Quando houver perda definitiva de peças que possam ser repostas, o locatário paga a reposição da peça. Caso a peça não possa ser reposta a empresa cobra uma taxa que varia conforme o comprometimento do uso do brinquedo. Essa taxa é cobrada porque provavelmente o brinquedo perderá valor na hora de ser colocado novamente para locação. Caso o brinquedo fique inutilizado, a taxa a ser cobrada é de $70 \%$ do valor de mercado do brinquedo e o locatário pode ficar com o item, pois o mesmo será substituído. Tais propostas de conserto e compra foram consideradas satisfatórias pelos pais que apresentaram essa preocupação

Durante as entrevistas alguns pais relataram que seus filhos brincam muito pouco com brinquedos porque acabam tendo mais interesse em utilizar tablets e smartphones para jogar e assistir desenhos. Surgiu então a ideia de proporcionar, além da locação de brinquedos, uma curadoria de conteúdo relacionado a brincadeiras para crianças de cada faixa etária. A ideia seria sugerir brinquedos e dar dicas pedagógicas para otimizar o seu uso e incentivar o brincar entre pais e filhos, estimulando as interações familiares e que a criança use mais a imaginação. Outra questão interessante foi a percepção de alguns pais sobre a possibilidade de usar a locação de brinquedos para transmissão de valores, pois as crianças aprenderiam desde cedo a cuidar bem dos itens que serão usados por outras pessoas.

\subsection{Mínimo Produto Viável - MVP}

Para testar se a proposta de valor e o serviço ofertado despertariam o interesse de clientes sem uma apresentação formal, foi elaborada uma landing page (Figura 6) que explica o funcionamento da locação de brinquedos. 


\section{Revista Gestão \& Sustentabilidade Grupo de Estudos em Operações e Sustentabilidade

Figura 6. Mínimo produto viável - Landing Page.

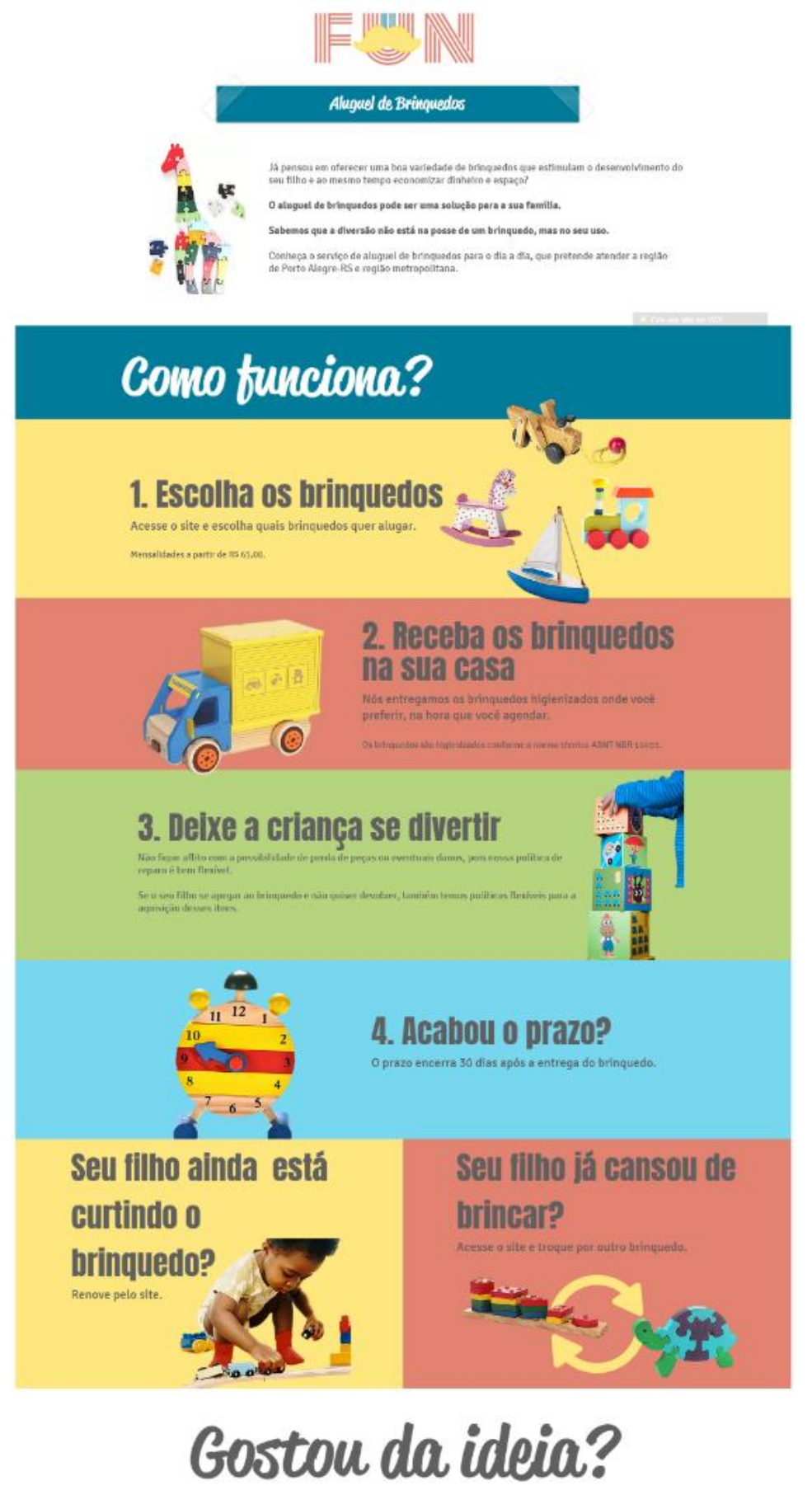

Quer ser notificado quando o serviço estiver disponivel?

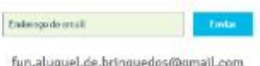

Fonte: Elaborado pelas autoras (2017).

A página foi desenvolvida considerando o aprendizado proporcionado pelas entrevistas. Nesta página é explicado como o serviço de locação de brinquedos funciona e foram incluídas informações-chave detectadas ao longo das entrevistas. O site consiste em um passo a passo das etapas necessárias para a locação de brinquedos e no final há um campo para os visitantes cadastrarem seu e-mail caso o serviço tenha despertado seu interesse. 
A recepção ao serviço foi interessante: $24 \%$ dos visitantes cadastraram-se para serem notificados quando o serviço estiver disponível. A landing page foi divulgada em grupos do Facebook e Whats App, em três dias recebeu 70 visitantes e 17 deles fizeram o cadastro como interessados.

\subsection{Análise dos resultados e construção do Canvas 3.0}

A terceira versão do modelo de negócio sofreu poucas alterações. Pelo feedback recebido ao longo das entrevistas foi possível verificar que a maioria dos entrevistados considera o problema proposto como algo a ser resolvido, validando a proposta de valor definida. Logo, não houve modificações relevantes nos seguintes componentes do quadro: proposta de valor, recursos principais, atividades-chave e parcerias principais. Os componentes modificados foram: segmento de clientes, canais, relacionamento com cliente e estrutura de custos.

O segmento de clientes foi alterado devido aos custos de entrega fora de cidade, restringindo o atendimento somente à Porto Alegre. A ideia de curadoria de conteúdo relacionado a brincadeiras infantis trouxe a possibilidade de incluir, a médio prazo, um blog no mix de canais da empresa. O objetivo do blog será fornecer conteúdo sobre brincadeiras com crianças visando aproximar pais e filhos e proporcionar às crianças a possibilidade de usufruir de uma brincadeira mais ativa ao invés de apenas consumir o conteúdo de tablets e smartphones. Foi incluída a curadoria de conteúdo no componente relacionamento com clientes, que poderá ser implementada a médio prazo.

A principal fonte de receita continua sendo a mensalidade do aluguel do brinquedo. Foi incluída a possibilidade de os pais comprarem itens que a criança realmente não quiser devolver, mas esta prática será considerada uma exceção à regra. A estrutura de custos projetada sofreu alterações com a exclusão do atendimento de cidades da região metropolitana de Porto Alegre para entrega dos itens locados sem cobrança de frete, além disso foi incluída uma previsão de custo fixo mensal com a manutenção do site. Essas mudanças culminaram no aumento dos custos fixos e na redução dos custos com materiais diretos

O faturamento máximo da empresa segue o mesmo, mas com as alterações nos custos mencionadas o resultado líquido chega a $\mathrm{R} \$ 8.850,00$. O retorno do investimento ocorreria em aproximadamente 16 meses de faturamento máximo, se mantida a distribuição do resultado líquido da empresa conforme sugerido anteriormente: $70 \%$ como remuneração dos investidores, $20 \%$ para reinvestir na empresa e $10 \%$ como reserva financeira. A Figura 7 apresenta o modelo de negócios Canvas 3.0. 


\section{Revista Gestão \& Sustentabilidade Grupo de Estudos em Operações e Sustentabilidade}

Figura 7. Modelo de negócios Canvas - versão 3.0.

\begin{tabular}{|c|c|c|c|c|c|c|c|}
\hline \multicolumn{7}{|c|}{ MODELO DE NEGOCIO - CANVAS - Locação de brinquedos para crianças em Porto Alegre } & versão 3.0 \\
\hline Parcerias principais & \multicolumn{2}{|l|}{ Atividades-chave } & \multicolumn{2}{|c|}{ Proposta de valor } & \multicolumn{2}{|c|}{ Relacionamento com cliente } & Segmentos de clientes \\
\hline Representantes de brinquedos & \multicolumn{2}{|c|}{ Pesquisa e compra de brinquedos } & \multirow{4}{*}{\multicolumn{2}{|c|}{$\begin{array}{l}\text { Oferecer de forma prática, } \\
\text { económica e sustentavel, } \\
\text { variados brinuquedos de } \\
\text { qualidade comprovada pelo } \\
\text { IIMETRO para criancas de zero } \\
\text { a seis anos desenvolverem suas } \\
\text { habilidades. }\end{array}$}} & \multicolumn{2}{|c|}{$\begin{array}{l}\text { Anüncios com Facebook Ads, } \\
\text { Instagram Ads e Google Adwords }\end{array}$} & \\
\hline Fornecedor de embalagens & \multicolumn{2}{|c|}{$\begin{array}{l}\text { Inventárí de brinquedos } \\
\text { adquiridos }\end{array}$} & & & \multirow{2}{*}{$\begin{array}{l}\text { Canal do } \\
\text { Youtube }\end{array}$} & \multirow{4}{*}{$\begin{array}{l}\text { Médio prazo- } \\
\text { brindes para } \\
\text { quem indicar } \\
\text { novos } \\
\text { clientes }\end{array}$} & $\begin{array}{l}\text { Pais de cranchas de } 0 \text { a } 6 \text { anos } \\
\text { que moram em Porto Alegre. }\end{array}$ \\
\hline & \multirow{2}{*}{\multicolumn{2}{|c|}{ Higienizaçăo e armazenamento }} & & & & & \\
\hline Fornecedor de material de limpeze & & & & & \multirow{2}{*}{$\begin{array}{l}\text { Médio prazo - } \\
\text { Curadoria de } \\
\text { conteưdo }\end{array}$} & & \\
\hline \multirow{7}{*}{$\begin{array}{l}\text { Desenvolvimento do site } \\
\text { (plataforma / desenvolvedor) }\end{array}$} & \multicolumn{2}{|c|}{ Agendar entrega / Coleta / Troca } & & & & & \\
\hline & \multicolumn{2}{|l|}{ Recursos-chave } & & & \multicolumn{2}{|l|}{ Canais } & \\
\hline & \multicolumn{2}{|c|}{ Site da empresa } & & & \multicolumn{2}{|c|}{ Site da empresa } & \\
\hline & Transpor & & & & Facebook & Instagram & \\
\hline & \multirow{2}{*}{\multicolumn{2}{|c|}{ Material armazenamento }} & & & Whats App & E-mail & \\
\hline & & & & & \multicolumn{2}{|c|}{ Youtube } & \\
\hline & \multicolumn{2}{|c|}{ Material de limpeza } & & & \multicolumn{2}{|c|}{ Médio prazo - Blog } & \\
\hline & \multirow{4}{*}{$\begin{array}{l}\text { Custos fixos: RS } 4000 \\
\text { - Plataforma site / } \\
\text {. hospedagem } \\
\text { : Contador } \\
\text { : Anúncios } \\
\text { IIternet / Telefone } \\
\text { Prólabore } \\
\text { Manutençăo do site }\end{array}$} & \multirow{4}{*}{\multicolumn{2}{|c|}{$\begin{array}{l}\text { Materiais diretos: RS } 25 \\
: \text { Material de Limpeza } \\
\text { Custos por transaçăo }\end{array}$}} & \multirow{2}{*}{\multicolumn{2}{|c|}{ Fontes de receita }} & & \\
\hline Estrutura de custos & & & & & & & \\
\hline \multirow{2}{*}{$\begin{array}{l}\text { Custos iniciais: RS } 100 \text { mil } \\
\vdots \text { Abertura empresa } \\
\vdots \text { Advogado } \\
\vdots \text { Estogue brinquedos } \\
\text { Embalagens } \\
\text { Site }\end{array}$} & & & & \multirow{2}{*}{\multicolumn{2}{|c|}{ 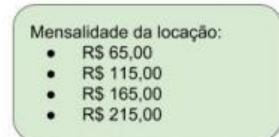 }} & & \\
\hline & & & & & & & \\
\hline
\end{tabular}

Fonte: Elaborado pelas autoras (2017).

\subsection{Aprendizado promovido pelo modelo de Desenvolvimento de Clientes}

Através das apresentações das suposições feitas acerca do modelo negócio da empresa, foi possível constatar que existe um mercado potencial para os serviços de locação de brinquedos em Porto Alegre. Inicialmente não se tinha certeza sobre quais eram os atributos essenciais para que o cliente percebesse valor na contratação do serviço. $\mathrm{O}$ foco inicial estava na possibilidade de ampliar o repertório de brincadeiras, com o decorrer dos testes foi percebido que a economia e segurança também são valores importantes na percepção do cliente.

Na primeira estrutura de custos supôs-se que a empresa poderia iniciar sua operação com um investimento inicial modesto, no entanto este palpite provou-se incorreto. Com um investimento baixo a empresa não teria retorno financeiro que viabilizasse sua operação. Ao ajustar o investimento pré-operacional e os custos envolvidos, houve uma melhora na expectativa de resultado financeiro. Ao longo das entrevistas foi identificado o conjunto de atributos essenciais do serviço, como a variedade e disponibilidade de brinquedos, que não seria possível com o investimento baixo em estoque.

O preço da mensalidade e a facilidade no processo de locação e entrega também são atributos relevantes. O preço da mensalidade proposta está um pouco acima do que a maioria dos pais acaba investindo na compra de brinquedos, mas considerando que os possíveis clientes percebem valor no fato de poderem diversificar os estímulos e economizar espaço, existe potencial para explorar as mensalidades estimadas.

As entrevistas trouxeram a percepção de que as mensalidades poderiam iniciar com um valor abaixo de cinquenta reais, no entanto o custo com a entrega dos produtos limita a possibilidade de reduzir a precificação. O custo com o transporte está potencializado ao máximo, mas conforme forem montadas as escalas de entrega, o valor poderá ser diluído. A logística de entrega acaba sendo a parte mais complexa e custosa da operação.

Um diferencial considerado inicialmente na proposta do negócio é a entrega dos brinquedos através de funcionários da empresa que explicariam o funcionamento do brinquedo e fariam a vistoria em conjunto com o cliente pessoalmente. A mesma lógica ocorreria com a coleta dos brinquedos. Durante os testes aventou-se a possibilidade de fazer isto nas primeiras locações dos clientes, visando estabelecer a relação de confiança entre ele e 


\section{Revista Gestão \& Sustentabilidade Grupo de Estudos em Operações e Sustentabilidade}

a empresa e entre a empresa e ele. Uma vez que esse laço estiver estabelecido, pode ser viável apenas entregar e coletar os produtos através de uma transportadora, o que poderia baratear as entregas e ampliar a área atendida.

O processo de aprendizado promovido pela etapa de Descoberta do Cliente do modelo sistematizado por Blank (2012) foi essencial para a lapidação de um modelo de negócio com potencial para atingir sucesso. O contato com possíveis clientes trouxe importantes insights que modificaram a estrutura pensada inicialmente para a empresa, redefinindo o enfoque de alguns elementos considerados como mais relevantes. Chegou-se, então, ao término do ciclo de Descoberta do Cliente com a certeza de que existe um problema que o consumidor deseja resolver e a solução apresentada parece satisfazer a essa necessidade.

\section{Considerações finais}

O principal objetivo dessa pesquisa foi elaborar um modelo de negócios para uma empresa de aluguel de brinquedos para crianças em Porto Alegre. A modelagem do negócio teve como base teórica o modelo de Desenvolvimento de Clientes sistematizado por Steve Blank. Este foi o método escolhido pela natureza inovadora da proposta de serviço.

O processo de Desenvolvimento de Clientes conta com duas etapas distintas: a pesquisa e a execução. A etapa de pesquisa está dividida em Descoberta do Cliente e Validação pelo Cliente. Este artigo focou no primeiro passo: descobrir clientes entusiasmados que confirmem a importância de solucionar o problema detectado com a solução apresentada. Ao definir o tipo de serviço prestado pela empresa não havia muitas certezas. Sabia-se da existência de empresas que prestam esse serviço em Porto Alegre, portanto existia o mercado. No entanto, ainda assim não era possível saber se a quantia de clientes seria suficiente para estabelecer o negócio e ter segurança quanto à viabilidade operacional e financeira.

Considera-se que o objetivo principal da pesquisa foi atingido através da consecução dos objetivos secundários estabelecidos, que possibilitaram realizar o ciclo de Descoberta do Cliente. Primeiro foi elaborado um modelo de negócios baseado em hipóteses iniciais; depois essas conjecturas foram testadas com uma mentora e com potenciais clientes; com o feedback recebido e aprendizado promovido pela apresentação das hipóteses foi construído um MVP de baixa fidelidade para testar o interesse de desconhecidos sobre o produto mínimo viável definido; e para completar chegou-se a uma versão mais evoluída do modelo de negócios.

Houve dificuldade para a construção da primeira versão do modelo de negócios. Apesar da elaboração do briefing com as principais características da empresa, existiam dúvidas quanto a cada definição colocada no papel. A primeira verificação dos custos e resultado financeiros estimados refletiu o grau de insegurança ao apontar um resultado abaixo do esperado. Expor as suposições iniciais para uma mentora com experiência no setor de comércio e serviço foi decisivo para projetar uma segunda versão do modelo de negócios. Em duas reuniões todo o modelo foi revisto, novos insights surgiram, culminando na evolução para o quadro Canvas 2.0. Com uma versão mais sólida do modelo de negócios foi o momento de apresentá-lo para potenciais clientes. As entrevistas geraram aprendizados que, por sua vez, motivaram novas reflexões acerca do modelo de negócios determinado. A dificuldade para agendar as entrevistas retratou um aspecto importante do dia a dia das famílias: mães e pais estão sempre envolvidos em muitas atividades e não tem tempo a perder. Esta perspectiva condicionou não apenas o serviço de locação, que precisa ser simples e fácil de utilizar, mas também a mecânica de testes idealizada. Foi necessário mudar de estratégia e focar em entrevistas por telefone e Skype. As entrevistas realizadas com usuários do serviço de locação demonstraram que muitas famílias acabam parando de alugar brinquedos porque entram na agitação das suas rotinas e esquecem da proposta da empresa. Com isso viu-se a importância de manter um relacionamento próximo, mas não invasivo, com os clientes. 


\section{Revista Gestão \& Sustentabilidade Grupo de Estudos em Operações e Sustentabilidade}

Uma das dificuldades encontradas em relação ao estabelecimento do negócio é a falta de informações sobre a operação do mercado em que a empresa vai atuar. Contar com bons fornecedores é fundamental para o sucesso da empresa, e por isso a busca por fornecedores confiáveis e qualificados sem ter conhecimento de mercado pode ser dificultosa. Os parceiroschave cruciais da empresa de locação são os representantes de brinquedos e desenvolvedores de e-commerce. Com o aprendizado gerado pelos testes iniciais foi possível apresentar a landing page com informações sobre o funcionamento do serviço e sua divulgação em redes sociais. Outras possibilidades de exposição são a busca de parcerias com eventos de consumo compartilhado como Feiras, Brechós e eventos de Empreendedorismo Feminino.

A elaboração de um MVP de alta fidelidade não foi realizada no decorrer dessa pesquisa, principalmente pelos custos envolvidos na sua estruturação. Existe a possibilidade de testar a locação de brinquedos com os entrevistados que se mostraram mais entusiasmados com a ideia e com os inscritos na landing page. A versão 3.0 do modelo de negócios da empresa é um conjunto de suposições que foram testadas, constituindo um modelo melhorado e com maior potencial para ser lucrativo, quando comparado a sua versão inicial. No entanto essa versão não deve ser considerada como uma versão final da estratégia do negócio, mas encarada como ponto de partida para o desafio de empreender.

Como limitação deste estudo está o número de entrevistas realizadas. 22 pais foram entrevistados, mas a agenda atribulada não permitiu que outros 13 pais que se mostraram interessados em participar da pesquisa fossem entrevistados. Esses elementos servem de sugestões para pesquisas futuras que busquem complementar o estudo inicial. Espera-se que o uso do método de Desenvolvimento de Clientes como base teórica para o planejamento de um empreendimento contribua para ampliar e incentivar a sua disseminação. Utilizar uma abordagem diferente da tradicional traz dificuldades, como a falta de literatura disponível que comprove seu sucesso, contudo gera grandes possibilidades de reflexão e aprendizado.

\section{Referências}

ABRINQ. Brinquedos 2017: Estatísticas. São Paulo, 2017. Disponível em <http://www.abrinq.com.br/download/ESTATISTICAS\%20\%20BRINQUEDOS\%202017.pdf>. Acesso em: 24 abr. 2017.

ALGAR, Ray. Collaborative Consumption. Leisure Report. Reino Unido, abr. 2007. Disponível em <http://www.oxygen-consulting.co.uk/insights/collaborative-consumption>. Acesso em: 24 abr. 2017.

BLANK, Steve. Do sonho a realização em 4 passos: estratégias para a criação de empresas de sucesso. São Paulo: Évora, 2012.

BLANK, Steve. DORF, Bob. Startup: Manual do Empreendedor o guia passo a passo para construir uma grande companhia. Rio de Janeiro: Alta Books, 2014.

BOTSMAN, Rachel. ROGERS, Roo. O que é meu é seu: como o consumo colaborativo vai mudar o nosso mundo. Porto Alegre: Bookman, 2011.

FARAH, Osvaldo Elias. CAVALCANTI, Marly. MARCONDES, Luciana Passos. Empreendedorismo estratégico: criação e gestão de pequenas empesas. São Paulo: Cengage Learning, 2008.

GIL, Antônio Carlos. Como Elaborar Projetos de Pesquisa. São Paulo: Atlas, 2002. Disponível em <https://professores.faccat.br/moodle/pluginfile.php/13410/mod_resource/content/1/como_ela borar_projeto_de_pesquisa_-_antonio_carlos_gil.pdf>. Acesso em: 05 mai. 2017. 
GERHARDT, Tatiana Engel. SILVEIRA, Denise Tolfo. Métodos de Pesquisa. Porto Alegre: Editora da UFRGS, 2009.

GLOBAL ENTREPRENEURSHIP MONITOR. Empreendedorismo no Brasil: 2016. Curitiba: $\quad$ IBQP, $2017 . \quad$ Disponível em <http://www.sebrae.com.br/Sebrae/Portal\%20Sebrae/Anexos/GEM\%20Nacional\%20\%20web.pdf >. Acesso em: 26 abr. 2018.

HISRICH, Robert. PETERS, Michael. Empreendedorismo. Porto Alegre: Bookman, 2004.

MALHOTRA, Naresh. Pesquisa de Marketing: uma orientação aplicada. Porto Alegre: Bookman, 2012.

MAURER, Angela Maria; BARCELlOS, Márcia Dutra de; FINGUEIRÓ, Paola Schmitt; CAMPOS, Simone Alves Pacheco de; SILVA, Virgínia Sebastião da. Yes, we also can! O desenvolvimento de iniciativas de consumo colaborativo no Brasil. BASE - Revista de Administração e Contabilidade da Unisinos, São Leopoldo, v. 12, n. 1. jan/mar 2015. Disponível em <http://www.lume.ufrgs.br/bitstream/handle/10183/122619/000968808.pdf?sequence=1>. Acesso em: 24 abr. 2017.

OLIVEIRA, André Jorge de. Como a internet das coisas vai atropelar o capitalismo (Entrevista com Jeremy Rifkin). Revista Galileu. Rio de Janeiro, fev. 2015. Disponível em $<$ http://revistagalileu.globo.com/Revista/noticia/2015/02/como-internet-das-coisas-vaiatropelar-o-capitalismo.html>. Acesso em: 04 set. 2016.

OSTERWALDER, Alexander; PIGNEUR, Yves. Business Model Generation - Inovação em Modelos de Negócios: um manual para visionários, inovadores e revolucionários. Rio de Janeiro, RJ: Alta Books, 2011. Disponível em <http://brazil.enactusglobal.org/wpcontent/uploads/sites/2/2017/01/Business-Model-Generation.pdf>. Acesso em 26 mar. 2017.

ROESCH, Sylvia Maria Azevedo. Projetos de Estágio e de Pesquisa em Administração. São Paulo: Atlas, 2012.

SANTOS, Andréia Mendes dos; GROSSI, Patricia Krieger. Infância comprada: hábitos de consumo na sociedade contemporânea. Revista Textos \& Contextos, Porto Alegre, v. 6, n. 2, $\mathrm{jul} / \mathrm{dez}$ 2007.

Disponível

em <http://repositorio.pucrs.br/dspace/bitstream/10923/8161/2/Infancia_comprada_habitos_de_c onsumo_na_sociedade_contemporanea.pdf>. Acesso em: 24 abr. 2017.

SCHUMPETER, J.A. (1997). Teoria do Desenvolvimento Econômico (M. S. Possas, Trad.). São Paulo: Editora Nova Cultural Ltda. (Obra original publicada em 1964).

SPC BRASIL. Consumo Infantil. 2015. Consumo Infantil. Disponível em <https://www.spcbrasil.org.br/uploads/st_imprensa/analise_consumo_infantil_setembro_2015 1.pdf>. Acesso em: 24 abr. 2017.

SPC BRASIL; CONFEDERAÇÃO NACIONAL DE DIRIGENTES LOJISTAS. (2017). Influência dos filhos sobre os pais nas compras de Natal de 2017. Disponível em <https://www.spcbrasil.org.br/pesquisas/pesquisa/3843 >. Acesso em: 26 abr. 2018.

THE NDP GROUP. (2017). Retail Tracking Service. Disponível em <https://www.npd.com/wps/portal/npd/us/news/press-releases/2017/us-toy-industry-grows-5percent-in-2016-exceeding--20-billion-the-npd-group-reports/>. Acesso em: 26 abr. 2018. 


\section{Revista Gestão \& Sustentabilidade Grupo de Estudos em Operações e Sustentabilidade

THE TOY ASSOCIATION. (2017). Global Sales Data. Disponível em $<$ http://www.toyassociation.org/ta/research/data/population/toys/research-anddata/data/global-sales-data.aspx >. Acesso em: 26 abr. 2018. 